\title{
Driving forces for and barriers to providing energy services: a study of local and regional energy companies in Sweden
}

\author{
Daniel Kindström, Mikael Ottosson and Patrik Thollander \\ Journal Article
}

\section{Tweet}

N.B.: When citing this work, cite the original article.

This is a copy of the original publication which is available at www.springerlink.com:

Daniel Kindström, Mikael Ottosson and Patrik Thollander, Driving forces for and barriers to providing energy services: a study of local and regional energy companies in Sweden, Energy Efficiency, 2017. 10(1), pp.21-39. http://dx.doi.org/10.1007/s12053-016-9437-8

Copyright: Springer Verlag (Germany) http://www.springerlink.com

Postprint available at: Linköping University Electronic Press

$\underline{\text { http://urn.kb.se/resolve?urn=urn:nbn:se:liu:diva-134119 }}$

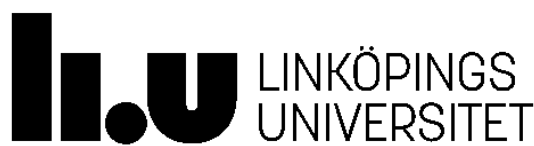




\title{
Driving forces for and barriers to providing energy services - A study of local and regional energy companies in Sweden
}

\begin{abstract}
Improving energy efficiency is a cornerstone in climate change mitigation, and energy services are portrayed as a promising market-based approach to achieve this. This paper examines the barriers to, and driving forces needed for, the implementation of energy services from the perspective of Swedish local and regional energy companies. This includes an analysis of the resources needed in three phases of energy service implementation, i.e., development, sales, and deployment. The results indicate a supply-side interest in providing energy services, with the major challenges being related to (a) intraorganizational issues such as a lack of strategic direction and intent and (b) a perceived lack of knowledge, interest, and trust on the part of potential energy service customers. The paper concludes with managerial and policy implications on how an increased focus and impact of energy service can be achieved among local and regional companies.
\end{abstract}

\section{Keywords}

Energy services, local and regional energy companies, EPC, ESCO, energy efficiency, barrier, driving force 


\section{Introduction}

Improving energy efficiency is a cornerstone in climate change mitigation, and energy services are portrayed as a promising market-based approach to achieve this. Existing energy service research to date has focused on describing actual service usage in various countries, regions, and sectors (see, e.g., Bertoldi et al., 2006; Okay \& Akman, 2010; Painuly et al., 2003; Vine, 2005). Although these studies have found some growth in energy services, this is still deemed slow and insufficient (Pätäri \& Sinkkonen, 2014). Several studies advocate for public support for energy service companies (ESCOs) or their customers as well as reduced legal and institutional barriers in the markets (Bertoldi et al., 2006; Painuly et al., 2003). As noted by Pätäri and Sinkkonen (2014), many studies of energy services have concentrated on evaluating either the outcome of individual energy service projects (Okkonen \& Suhonen, 2010; Sovacool, 2013; Wood \& Rowley, 2011) or the measures needed to improve them (Painuly et al., 2003; Soratana \& Marriott, 2010; Sorrell, 2007).

The European Energy Efficiency Directive (EED) emphasizes that "an integrated approach must be taken to tap all the existing energy saving potential, encompassing savings in the energy supply and the end-use sectors" (EC, 2011). To this end, the major focus research-wise has been toward general ESCOs (e.g., Vine, 2005). Very little research (except, e.g., Pätäri \& Sinkkonen, 2014; Hannon et al., 2013) has considered the energy companies' role, even though they are increasingly interested in moving from a traditional goods-oriented business model (i.e., producing, distributing, and selling electricity and heat) to a more service- or solution-based approach addressing the customer's needs. Many factors account for this transition toward services. Local and regional energy companies selling and distributing, for example, district heating face a future of assumed demand decline due to such factors as more energy-efficient housing and increased global warming, emphasizing the need to find new revenue streams for their businesses (Magnusson, 2012). Other issues such as the greening of corporate strategies, images, and brands (see, e.g., Dangelico \& Pontrandolfo, 2013) are also becoming more important for energy companies.

The present research takes as its starting point the supply side and the efforts of local and regional energy companies to implement energy services. These companies have many benefits that their competitors (e.g., general ESCOs and technical consultancies) lack, such as unique local and regional customer data on energy use and a local market presence with well-established customer relationships. These data offer a potential competitive advantage in that the companies understand which customers have the greatest opportunities for energy reduction. Further, on many energy service markets the supply side is limited to relatively few and large companies (such as technical consultancies, etc.) which can limit the development regarding energy services. The involvement of local and regional energy companies in providing energy services may have the potential to further stimulate the supply side and may consequently improve the market opportunities for energy services. So far, only a few papers have studied the energy service market in Sweden (e.g. Backlund and Eidenskog, 2013 and Lindgren-Soroye \& Nilsson, 2010), and no paper has, to the authors' awareness, studied the energy service market from the local and regional energy companies' perspective.

Despite the sometimes high expectations regarding energy services from, e.g., the EED, progress within the EU has so far often been limited and many suppliers, including energy companies, implementing energy service initiatives have struggled (Pätäri \& Sinkkonen, 2014). The transition to services in other industries has also been highlighted as problematic and entailing various challenges (Gebauer et al., 2005; Lightfoot et al., 2013). It is therefore of interest, and the overall aim for this research, to investigate and identify key barriers to and driving forces for implementation of energy services by energy companies. Existing studies of what inhibits and promotes energy companies 
supplying energy services are very scarce, one exception being Vine (2005), who identified barriers facing the general ESCO industry (there are also some in-depth market reports regarding ESCOs, see e.g. Bertoldi et al. (2014)). One may thus conclude that more research is needed in this area, both from a management perspective, but also to gain knowledge for policymakers on how to design adequate policy structures to overcome the barriers in the market.

Conceptually, this research approaches energy service implementation as a process comprising three phases, i.e., developing, selling, and deploying energy services (Kindström \& Kowalkowski, 2009; Tuli et al., 2007), each requiring organizational resources. Our analysis, in addition to identifying barriers and driving forces, also includes a mapping of the resources needed in the three phases of the energy service implementation process. This is conducted in Swedish local and regional energy companies working with energy services.

This paper first discusses the energy service concept and the Swedish market for energy services. In sections three and four, the theoretical framework and methods are introduced. Sections five and six are dedicated to presenting the results and discussing the implications of these. Finally, in section seven, the major conclusions are outlined.

\section{The energy service concept and the Swedish market for energy services}

\subsection{The energy service concept}

There is no single definition of energy services. According to the EED, 'energy service' means the physical benefit, utility or good derived from a combination of energy with energy efficient technology or with action, which may include the operations, maintenance and control necessary to deliver the service, which is delivered on the basis of a contract and in normal circumstances has proven to result in verifiable and measurable or estimable energy efficiency improvement or primary energy savings” (EC, 2011). While some definitions focus on the product sold (Greening et al., 2000), others focus on the benefits for the customer (Sorrell, 2007). Bertoldi et al. (2006, p. 1820) propose that "energy services include a variety of activities, such as energy analysis and audits, energy management, project design and implementation, maintenance and operation, monitoring and evaluation of savings, property management, and energy and equipment supply.” In this paper, we follow this definition and analyze both direct and indirect services (see, e.g., Bergmasth \& Strid, 2004). Direct services are ones that directly and tangibly affect the customer, e.g., changing lights or ventilation equipment on site. Indirect services are ones that, on the other hand, indirectly and intangibly affect the customer, such as selling information by means of an energy audit the customer can act on in a subsequent step. We can also separate basic direct services (e.g., selling information and analysis to customers) from more advanced services (e.g., managing activities and performance for customers).

Many services are, however, complex and often contain both direct and indirect elements. Examples of this are, e.g., energy performance services, such as different versions of EPCs. Such services usually have higher potential regarding reducing energy use and/or energy costs, but also typically involve more risk. Different types of services also demand different degrees of involvement from the customers in the value-creation process. Value propositions in the basic services (e.g., selling analysis of current energy use) are geared toward a more passive transfer of (potential) value. Managing activities and performance contracts at customer sites instead emphasize high customer involvement and thus depend more on cooperation and participation in order to succeed.

\subsection{The energy service market in Sweden}


Energy services are an important part of Sweden's implementation of the EED. Several other policy instruments affect the market, at least indirectly, such as different support schemes (e.g., support for maintenance, renovation or rebuild, and expansion in the building sector), the Program for Improving Energy Efficiency in Energy-intensive Industry (PFE), and the Energy Auditing Program. The ESCO market in Sweden started to take off after the electricity and gas market deregulation in 1996 (Bergmasth et al., 1999). Traditionally, energy services in Sweden have explored the public sector and, in particular, the modernization of buildings. Historically, the energy service market in Sweden has, however, grown quite slowly in terms of sales in relation to high expectations (Bergmasth \& Strid, 2004). This also holds for many other international markets (see, e.g., Bertoldi et al., 2006; Okay \& Akman, 2010; Painuly et al., 2003; Vine, 2005). In their thesis, Bergmasth and Strid (2004) found that the demand for energy services at the time of their research was weak, that energy companies did not always have the expertise to develop energy services, and that for some types of advanced energy services the high transaction costs constitute a barrier. Moreover, they found that energy companies primarily offered indirect energy services, they were unaware of their customer needs, and there was a lack of strategic resources targeting energy services. In recent reports, it has been stated that several Swedish energy companies have started to offer energy services to their customers, but that the development of these services is still in its infancy (Sernhed \& Jeppesen, 2009; Sernhed \& Skoglund, 2012). The Swedish Energy Agency states in its latest market report that the market for energy services in Sweden has indeed developed since 2000, but that this development has subsided in recent years (SEA, 2013).

The Joint Research Center, JRC, regularly publish an ESCO market report. In the most recent report, Bertoldi et al. (2014), presents a survey of the EU ESCO-market in which each market is analyzed regarding e.g. terms of barriers, market development, and policy mechanisms. In another similar publication from the same research institute, results for non-EU ESCO markets are also presented (Panev et al. 2014).

In this paper, we focus on local and regional energy providers. As argued above, these actors have many reasons for increasing their focus on service provision. However, other types of companies are indeed offering energy services in the Swedish market today (see Table 1). There are very few companies in Sweden that are solely focusing on energy services; this instead tends to be a relatively small part of the companies' total business portfolio.

Table 1. Examples of energy service providers in the Swedish market and the types of services typically offered (based on SEA 2013, p. 32).

\begin{tabular}{|l|l|}
\hline \multicolumn{2}{|c|}{ Energy service providers in the Swedish market } \\
\hline Company category & Type of service offered \\
\hline $\begin{array}{l}\text { Product-based companies } \\
\text { selling e.g. building or } \\
\text { ventilation components }\end{array}$ & $\begin{array}{l}\text { Energy services often related to } \\
\text { the companies' core product. }\end{array}$ \\
\hline $\begin{array}{l}\text { Facilities and property } \\
\text { management companies }\end{array}$ & $\begin{array}{l}\text { Typically facility management } \\
\text { contracts that also involve } \\
\text { energy monitoring and } \\
\text { activities. }\end{array}$ \\
\hline $\begin{array}{l}\text { Operations and maintenance } \\
\text { companies }\end{array}$ & $\begin{array}{l}\text { Mostly direct services such as } \\
\text { changing ventilation, but also } \\
\text { systems for monitoring energy } \\
\text { use. }\end{array}$ \\
\hline
\end{tabular}




\begin{tabular}{|l|l|}
\hline Technical consultancies & $\begin{array}{l}\text { Mostly indirect services such as } \\
\text { analysis. }\end{array}$ \\
\hline Energy companies & $\begin{array}{l}\text { Direct and indirect services } \\
\text { stretching from energy } \\
\text { information sales to EPC. }\end{array}$ \\
\hline Construction companies & $\begin{array}{l}\text { Typically direct services } \\
\text { focused on managing housing } \\
\text { projects for its members or } \\
\text { customers }\end{array}$ \\
\hline
\end{tabular}

The local and regional energy company sector is highly mature, commodity-based with homogeneous products (e.g., district heating and electricity), and has little differentiation between actors. The longterm trend has been for fewer companies to compete in slowly growing, or even stagnant, markets. An example is the electricity market, where electricity usage in Sweden was at the same level in 2013 as in 1990 (i.e., approximately $140 \mathrm{TWh} /$ year). Furthermore, many companies in the market are municipally owned, and therefore subject to public policy instruments and legislation that, among other things, force them to promote increased energy efficiency (e.g., EC, 2012). What is needed is new research and answers to issues related to how the local and regional energy companies can develop their business to allow for the successful development, sales, and delivery of energy services.

\section{Theory}

\subsection{Transitioning toward energy service provision: benefits and challenges}

For local and regional energy companies, an increased concentration on energy services may be one strategy for countering slow growth or stagnation. A transition from traditional bulk production to an increased focus on services could have multiple benefits (see, e.g., Eggert et al., 2014; Ulaga \& Reinartz, 2011), such as:

- services are generally more countercyclical than are goods;

- services typically have higher operating margins than do bulk products such as heat;

- services can create deeper relationships with customers;

- $\quad$ services can create differentiation opportunities and new avenues for growth; and

- services typically require less fixed investment.

However, realizing these benefits is not straightforward, and many firms in other industries that have extended their portfolios with services are struggling (Chirumalla, 2013; Ulaga \& Reinartz, 2011). Service research sometimes refers to this as the service paradox (Gebauer et al., 2005) or the existence of a profitability hurdle (Visnjic \& Van Looy, 2013), meaning, roughly, that firms cannot translate their investments in service and service-related resources into the expected returns.

Transitioning toward an increased emphasis on services consequently involves challenges, both internal and external (Gebauer et al., 2005; Ulaga \& Loveland, 2014), and the process typically must be carefully managed to succeed (Matthyssens \& Vandenbempt, 2010; Ulaga \& Reinartz, 2011). Understanding what is needed as firms move into services, as well as understanding more serviceoriented value propositions, is therefore crucial. An important first step is to open up the former "black box" of the energy service supply and examine the driving forces of and barriers to energy service provision from the perspective of the energy companies. 
As argued in the introduction, this research treats energy service implementation as a process comprising three phases: the development, sales, and deployment phases (Kindström \& Kowalkowski, 2009; Tuli et al., 2007). At the center of this process are the resources that the companies control or have access to. According to Barney (1991, p. 101), a firm's resources are "all assets, capabilities, organizational processes, firm attributes, information, knowledge, etc. controlled by a firm that enable the firm to conceive of and implement strategies that improve its efficiency and effectiveness."

Resources can be categorized by how, and where, they act or integrate with other resources and actors. However, not all firm resources contribute directly to competitive advantage, so energy companies must understand what resources to develop and nurture. Understanding the energy companies' resource base thus becomes important in order to improve our understanding of what hinders and drives energy service provision.

\section{Method}

\subsection{Research process and data collection}

To fulfill our aim and answer our research questions, a questionnaire was designed to enable a broad perspective on the driving forces and barriers perceived by local and regional actors in the Swedish energy company market. As formulating the questionnaire required a thorough understanding of the current state of the Swedish energy service market, as a first step, we conducted 45 qualitative indepth semi-structured interviews with three categories of respondents (see Table 1) to gain a sufficient understanding of the market and to be able to design an appropriate questionnaire. This was necessary due to the relative scarcity of research into energy companies offering energy services.

Table 2: Respondents in the initial interviews.

\begin{tabular}{|l|l|l|}
\hline Actor & Description & No. of respondents \\
\hline Energy companies & $\begin{array}{l}\text { Senior managers, head of } \\
\text { energy services, service } \\
\text { technicians, and energy experts }\end{array}$ & 15 \\
\hline Energy service consultancies & $\begin{array}{l}\text { Technical consultancies and } \\
\text { installation firms }\end{array}$ & 10 \\
\hline Customers & $\begin{array}{l}\text { Private and public facility } \\
\text { owners, industrial firms }\end{array}$ & 20 \\
\hline
\end{tabular}

Both interviews and a questionnaire were used to strengthen the findings of the study in terms of their usefulness both to the energy research field and to practitioners. Furthermore, this research strategy minimized the bias inherent in relying on data solely from personal interviews. Specifically, combining interviews with the questionnaire was expected to facilitate an in-depth understanding of both the contextual factors and underlying processes influencing the local and regional energy companies' development of energy services, and to foster a wider perspective on barriers and driving forces. Based on the initial interviews and grounded in the theoretical background as well as in previous research and governmental reports, the questionnaire was designed to explore barriers and driving forces, structured around the phases of the conceptualized service process (please see Appendix 1 for the questionnaire). 
Approximately 125 small, medium-sized, and large local and regional energy companies ${ }^{1}$ operate in Sweden. The chosen target group for the questionnaire is, however, smaller, comprising energy companies active in the energy services network of the Swedish trade organization for local and regional energy companies (Swedenergy). This target group, comprised of 37 companies, was chosen, as these firms represent local and regional energy companies currently actively and consciously working on energy services. One important assumption of the study was that companies not active in the trade organizations network were also not active suppliers of energy services. As such, they were deemed to have limited experience of relevant barriers and driving forces and, consequently, would be unable to contribute to this particular line of questioning.

The implemented selection process therefore resembles a theoretical sampling process (Eisenhardt \& Graebner, 2007) commonly used in qualitative research. This process means that the selection is not statistically representative of the total population of Swedish energy companies, as data commonly are in large-scale hypothesis testing research. As the purpose of the research is to increase our understanding of the driving forces, barriers, and associated resources for local and regional energy companies attempting to become energy service providers, theoretical (instead of random or stratified) sampling is appropriate since the selected target companies are particularly suitable for illuminating and extending our understanding of the analyzed phenomena.

In total, 37 Swedish energy companies received questionnaires, with a total of 96 respondents, resulting in 32 responses (representing 23 different local and regional energy companies). These responses collectively represent about half of the total national turnover of the approximately 125 local and regional energy companies constituting the total market. As the response rate is limited to 23 individual companies our results must however be treated with some caution. Conducting a study of such a small national market as Sweden is evidently not without challenges methodologically when it comes to validity. Through the combined approach used in this paper incorporating both interviews and a questionnaire, we have attempted, inspired by Yin (1994), to maximize the validity of the study, and by using analytical generalization, the study can still provide some level of generalization. In the survey, all respondents were asked to rate their level of knowledge of energy services; all responded that their knowledge level was high (five or above on a seven-point Likert scale), indicating that the questionnaire was sent to appropriate respondents and thus also increasing the validity of the findings. The respondents included business unit managers, energy engineers, energy service sales managers, energy service project leaders, energy service product managers, and production and service technicians. This diversity reflects the fact that energy service issues are handled by different positions in different firms.

\subsection{Data analysis}

The data from the initial interviews were summarized and categorized according to our guiding research aim concerning resources, barriers, and driving forces. This can be referred to as structural coding, which is suitable for explorative studies of multiple actors in which a semi-structured approach is applied (Saldana, 2009). The questionnaire data were analyzed quantitatively using descriptive analyses and ranked analyses (based on the Likert scale responses), as well as qualitatively contrasted with the interviews. Preliminary analyses were discussed in two workshops held at Swedenergy's network meeting for energy services. The primary aim of these workshops was to validate the preliminary results and to communicate the findings to the participating local and regional

\footnotetext{
${ }^{1}$ These were identified using self-reported industry codes (SNI 35.300), excluding very small firms (with fewer than five employees and under SEK 10 million turnover) and non-energy firms. As several firms did not report all industry codes, a number of firms were finally added to and removed from the sample by the researchers.
} 
energy companies and other stakeholders on the Swedish market. Stewart and Shamdasani (1990) have stressed that workshops and focus group discussions can strengthen analyses as they, for example, can enable the clarification of ambiguities.

\section{Results}

The following sections are structured around the research aim. First, the results regarding the resources needed for developing, selling, and deploying energy services are presented and discussed. Then the results regarding barriers to and driving forces for energy service provision by local and regional energy companies are examined.

\subsection{Delivering, selling, and deploying energy services: a resource perspective}

\subsubsection{Types of services offered and how they are sold and deployed in the market}

First, we asked the respondents to indicate which of the energy services listed in Table 3 their company offers. We found that, of the 23 responding local and regional energy companies, all but one offered at least one type of direct or indirect energy service in their business portfolios. The list of energy services was based on prior research and governmental reports (e.g., SEA, 2013) and the respondents had the possibility to add additional energy services not yet included in the given list. Three respondents opted to do this. Those three were collapsed into the category $\mathrm{Other}^{2}$ (see Table 3). The respondents could give multiple responses (i.e., to indicate the range of energy services offered). Table 3 shows the distribution of the provided energy services separated into basic and advanced energy services. Moreover, the number of responses and the number of energy companies that offer each type of energy service are displayed in the second and third columns, respectively.

Table 3: Overview of the responding local and regional energy companies offered energy services

\begin{tabular}{lcr}
\hline Type of energy service & Number $^{*}$ & Percentage $^{* *}$ \\
\hline Basic energy services & 21 & 91 \\
Energy statistics and information & 16 & 70 \\
Energy audits & 18 & 78 \\
Energy analysis and advice & & 61 \\
Advanced energy services & 14 & 22 \\
Direct improvement of energy efficiency by the customer & 5 & 70 \\
Financing of investments by the customer & 16 & 43 \\
Operations and maintenance & 10 & 13 \\
Functional contracts (e.g., contracts agreeing on a set indoor temperature) & 3 & \\
Other
\end{tabular}

Add up to more than 23 firms and 100\%, respectively due to the fact that the respondents could give multiple responses

The results from Table 3 show that the majority of firms offer basic energy services, whereas energy statistics and information is the energy service that nearly all firms in the sample provide. This is in

\footnotetext{
${ }^{2}$ The three were "Delivery of metering/metering value for tap hot water/cold water," “dimensioning support for district heating installation, installation and administrative support for sales of solar cells for micro production," and "energy declarations, lighting audit."
} 
line with the previous research by Bergmasth and Strid (2004). When it comes to advanced energy services, direct improvements in energy efficiency at the customer site and energy services that entail operations and maintenance are the most frequently provided.

An important aspect in understanding the energy service supply side is to map how energy services are supplied to the market today. In the present research, this was operationalized in two activities, i.e., selling and deploying energy services and developing energy services being seen as a primarily internal activity preceding the actual market offer. Figure 1 outlines the selling mechanisms used by the studied energy companies.

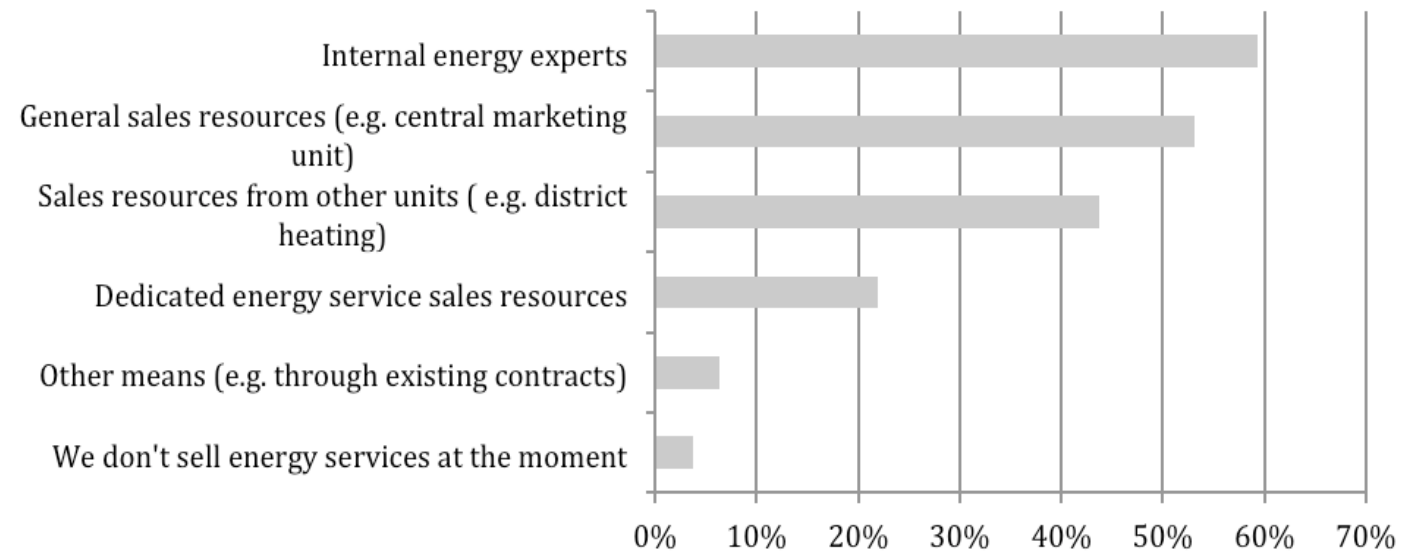

Figure 1. How energy services are sold by the studied local and regional energy companies, as reported by the respondents (percentage of respondents in each category). Respondents could indicate multiple responses.

The responses indicate that energy services are sold through various resources and channels, the most frequently used ones being internal technical energy experts as well as general sales resources not exclusively tied to energy services (e.g., a central sales and marketing organization or sales resources residing in various other organizational units). One shortcoming, however, is that the research did not indicate the levels of success achieved by the various channels. Evidence from interviews as well as insights from other industries (Reinartz \& Ulaga, 2008; Ulaga \& Reinartz, 2011) indicate less commitment, and consequently lower sales, via more general channels than via more direct and dedicated channels. Findings from service initiatives in other industries, however, are inconclusive as to whether traditional product-selling companies moving into services should create dedicated sales forces focusing solely on services. Some researchers have found that such sales forces could be used to kick-start service sales but might also create conflicts between service and product sales organizations (e.g., regarding who should approach which customers) (Kindström et al., 2015), whereas other research argues that dedicated service sales resources might be necessary (Reinartz \& Ulaga, 2008; Ulaga \& Loveland, 2014).

Internal energy experts constitute a widely used sales mechanism, as demonstrated in Figure 1. Similarly, Kindström et al. (2015) find, in studying manufacturing companies, that using the service deployment organization (such as internal energy experts) can indeed often be a key success factor in increasing the sales of services in general.

As with energy services sales, it is also of interest to look at how energy services are deployed to the market by the energy companies. The results of the questionnaire regarding the deployment of energy services are outlined in Figure 2. 


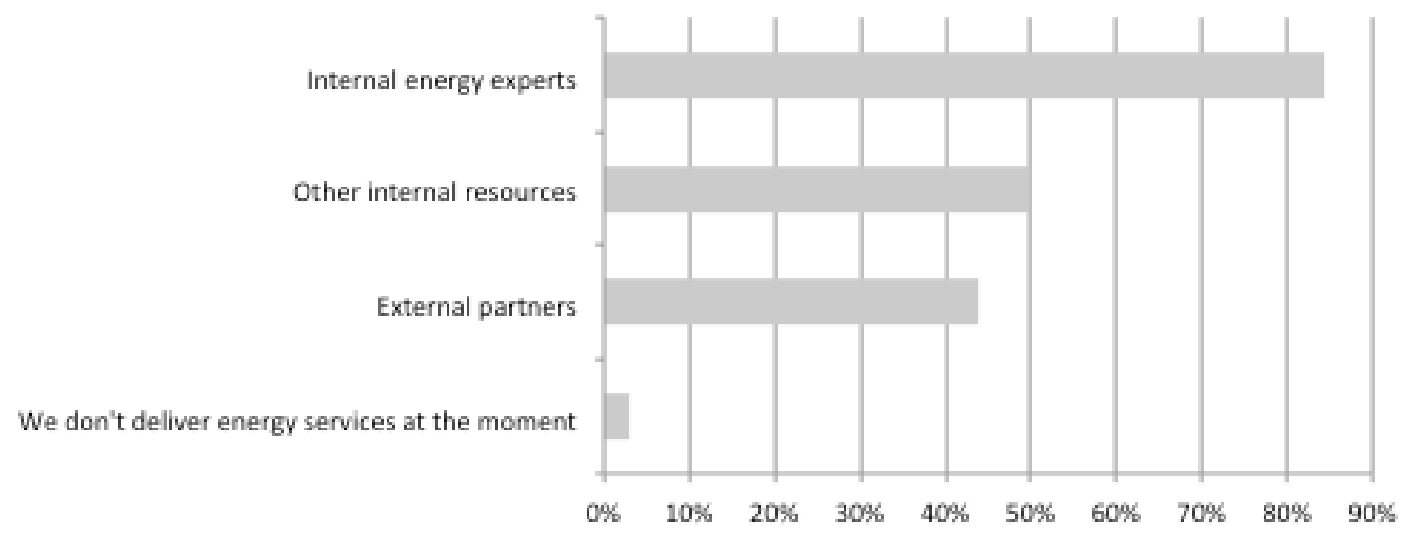

Figure 2. How energy services are deployed by the studied local and regional energy companies, as reported by the respondents (percentage of respondents in each category). Respondents could indicate multiple responses.

The usual approach among the studied energy companies is for specialized internal resources (socalled technical energy experts or other specialists) to deploy energy services. However, a relatively high number of companies also relied either on internal resources from other areas within the company (e.g., district heating service engineers) or on external partners to handle energy service deployment. Our interviews revealed that such external partners could, for example, be firms specialized in maintenance, electrical engineering, or technical consultancy firms. This could indicate that the competences needed for deploying energy services among energy companies are not readily available and that, in the long run, this could constitute a bottleneck for growth. In addition, with several actors involved in deployment, coordinating these resources can become a problem in the future.

\subsubsection{Availability of energy service resources in Swedish companies}

To provide energy services effectively, companies need to have access to the necessary resources. Findings from this study regarding resource availability, structured around the three-phase conceptualization (development, sale, and deployment) of energy service implementation, are presented in Figure 3.

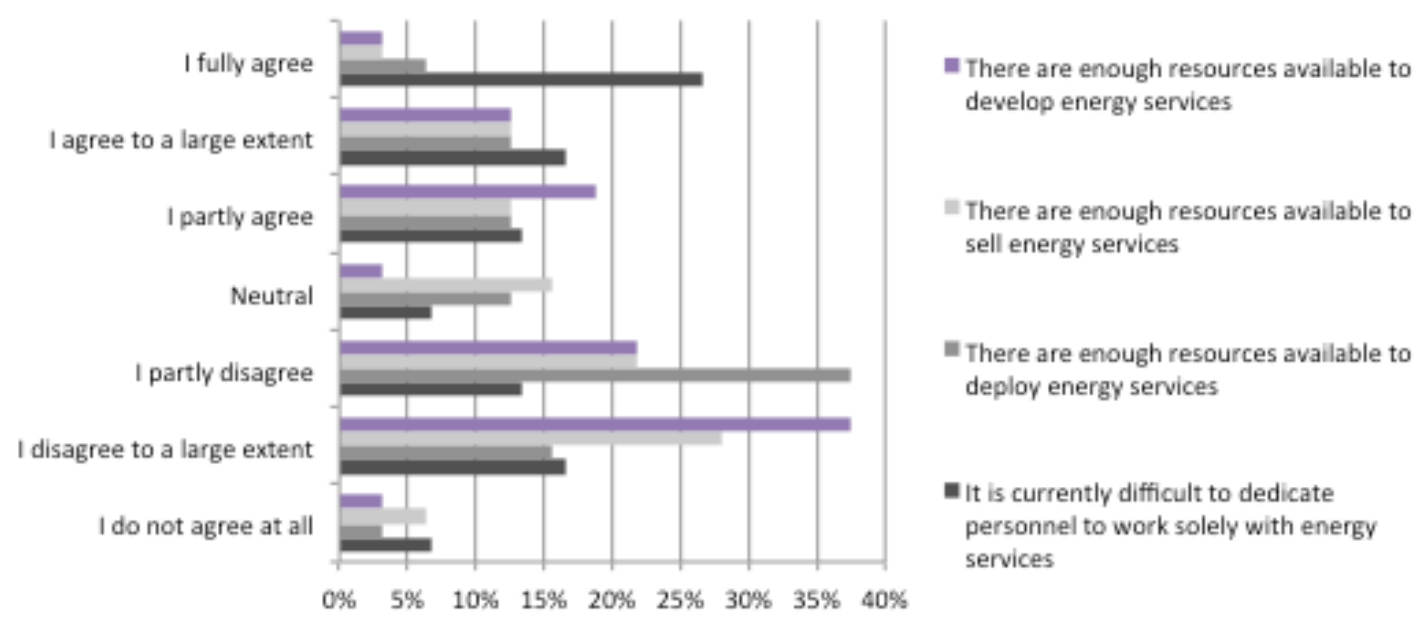

Figure 3. The availability of resources for developing, selling, and deploying energy services, as reported by the respondents (percentage of respondents in each category). 
These findings highlight a key issue (and potential barrier) in implementing energy services, namely, a perceived lack of resources in all three phases (there is a general tendency in Figure 3 that the respondents disagree with the statement that resources are available). Regarding the resources needed to develop new, or improve existing, energy services, the overall results indicate that the available resources are perceived as being insufficient by most companies. This result was also present in the previous study by Bergmasth and Strid (2004), which indicated a lack of strategic emphasis on energy services. Moreover, for selling and deploying energy services, there is a general perceived lack of resources with similar distributions among the respondents. There is a slight difference in that there are more neutral responses regarding resources for selling and deploying energy services. This could be due to the fact that several companies are relatively early in the implementation process and as such have not experienced resources challenges in those areas yet.

An increased service focus in firms requires resource development (cf. Barney \& Hesterley, 2005), especially in terms of resource and competence availability. In many firms, this might require an extension of the resource base by acquiring or cooperating with external firms (see also Figure 2 above), such as installation firms, to secure the resources and competences needed to succeed in the energy service market. This especially holds for energy companies that intend to offer more advanced energy services that require more direct interaction with their customers' processes and as they typically require more specialized knowledge. In sum, the results demonstrate a need in the sector to acquire, develop, and dedicate more resources to energy services in all phases of the service process.

The reasons for the perceived lack of resources, as demonstrated in Figure 3, can vary, but the present findings point in two main directions. First, although many companies state that energy services are indeed part of their strategic agendas, they also mention the lack of clear strategic intent and of associated energy service goals. This apparent paradox apparently leads to an unwillingness to commit resources to energy services and also creates internal conflict in the companies, as the traditional product business takes priority when existing resources are allocated. Without clear goals and objectives for energy services, a budding service-oriented business risks losing resource allocation struggles to the product-oriented traditional business. This also indicates, as seen in our initial interviews, that in many of the firms, the initiative to invest in energy services was based on ad hoc decisions (e.g., stemming from senior personnel's' interest or external expectations) rather than on thorough strategic decision-making processes. This emphasizes that these firms need to make committable strategic decisions regarding the future strategic directions of their energy services (cf. Prahalad \& Doz, 1989).

Second, as most studied companies are still in the early phases of implementing energy services, and are struggling going forward, they seem to have become stuck in a negative loop. Consequently, as their energy service sales are relatively modest, it is difficult to access the needed resources, which in turn means that they cannot increase their sales sufficiently. Several energy companies indicate that it is indeed difficult to dedicate resources to energy service-related activities (as seen in Figure 3). One company actually spun off its entire energy service business into a completely new company in an attempt to address this issue.

\subsubsection{Lack of competence}

Figure 4 illustrates the perceived difficulty of finding the needed competences (to be able to deploy value-adding energy services with sufficient quality) in all phases of the energy service implementation process (there is a general tendency in Figure 4 that the respondents agree with the statement that competences are difficult to find). The perceived difficulties could be explained by 
several factors, but this study identifies three in particular. First, the lack of strategic commitment inhibits any development incentives. Second, the lack of experience in energy services in the studied companies, and the relative immaturity of such services as a whole, results in a natural lack of relevant competences early in the implementation process. Finally, the competences needed for energy services, especially more advanced ones, are in general scarce on the market as a whole (as indicated by several market actors apart from the energy companies).

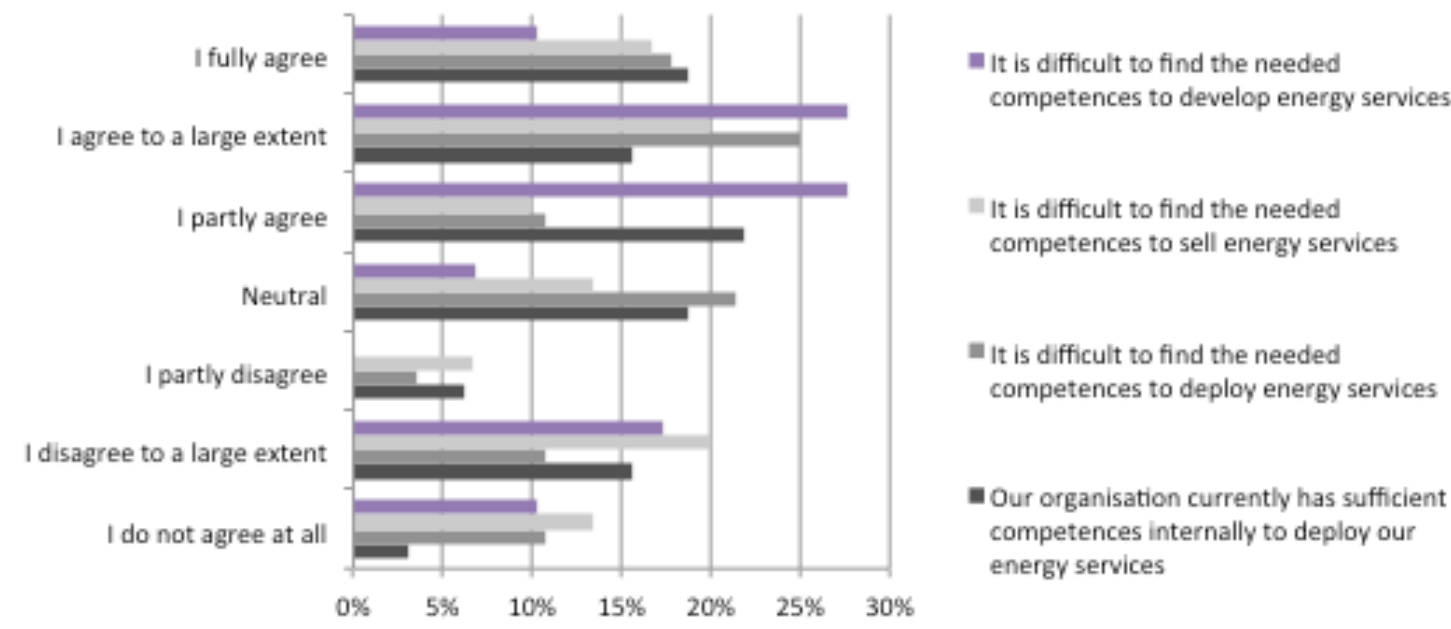

Figure 4. The difficulty in finding the needed competences to develop, sell, and deploy energy services, as well as the difficulty of dedicating personnel to work solely on energy services, as reported by the respondents (percentage of respondents in each category).

Most respondents, for example due to the challenge of finding the needed competences, perceive developing energy services as difficult (more so than for selling and deploying), mirroring the findings in Figure 3. This is perhaps not very surprising, as these companies are often new to these services and need to build the competence not only to develop services but also to understand what services to develop. Driven primarily by legislation, more basic indirect energy services, such as providing energy audits, are well defined, but many actors struggle when they try to move into more advanced energy services that require more specialized competences. This problem has also been identified in research into advanced energy services such as EPCs (e.g., Pätäri \& Sinkkonen, 2014; Hannon et al., 2013). EPCs have experienced difficulties making inroads into the Swedish market, and our studied companies as well as customers that we have interviewed are unsure as to how to handle these more advanced contracts (see also SEA, 2013). Interestingly, the finding that customers were not familiar with or interested in EPCs was already found to be the case in Vine's (2005) survey of the Swedish market, indicating that, even a decade later, EPCs still have some way to go before being completely accepted in the market.

In summary, the Swedish energy service market seems to suffer from a lack of resources and competences, a matter calling for further research into how to tackle this challenge, not least policyoriented. One possibility is to certify energy service personnel, with certification also including competence-enhancing activities. Another possibility is to increase the number of standardized services, for example, by developing and offering standard service modules to enable them to be delivered by a wider range of resources (with less specialized competence profiles). Some services might even be automated, minimizing the competence problem during deployment. Previous energy service research has, to a certain extent, advocated for certification and standardization to increase the quality, which is largely dependent on the deployment, of the services sold (Bertoldi et al., 2006; 
Marino et al., 2011). What should be considered, however, is that such service standardization primarily applies to more basic services such as statistics and audits, while more advanced services, such as operation and performance contracts, may be more difficult to standardize given their highly customized and site-specific nature.

\subsection{Barriers to energy services in the analyzed companies}

The perceived barriers to the successful implementation of energy services can be divided into external and internal barriers. External barriers are primarily related to factors outside the company, while internal barriers are primarily related to factors pertaining to the energy company itself. Figure 5 illustrates the respondents' perceived barriers to energy services.

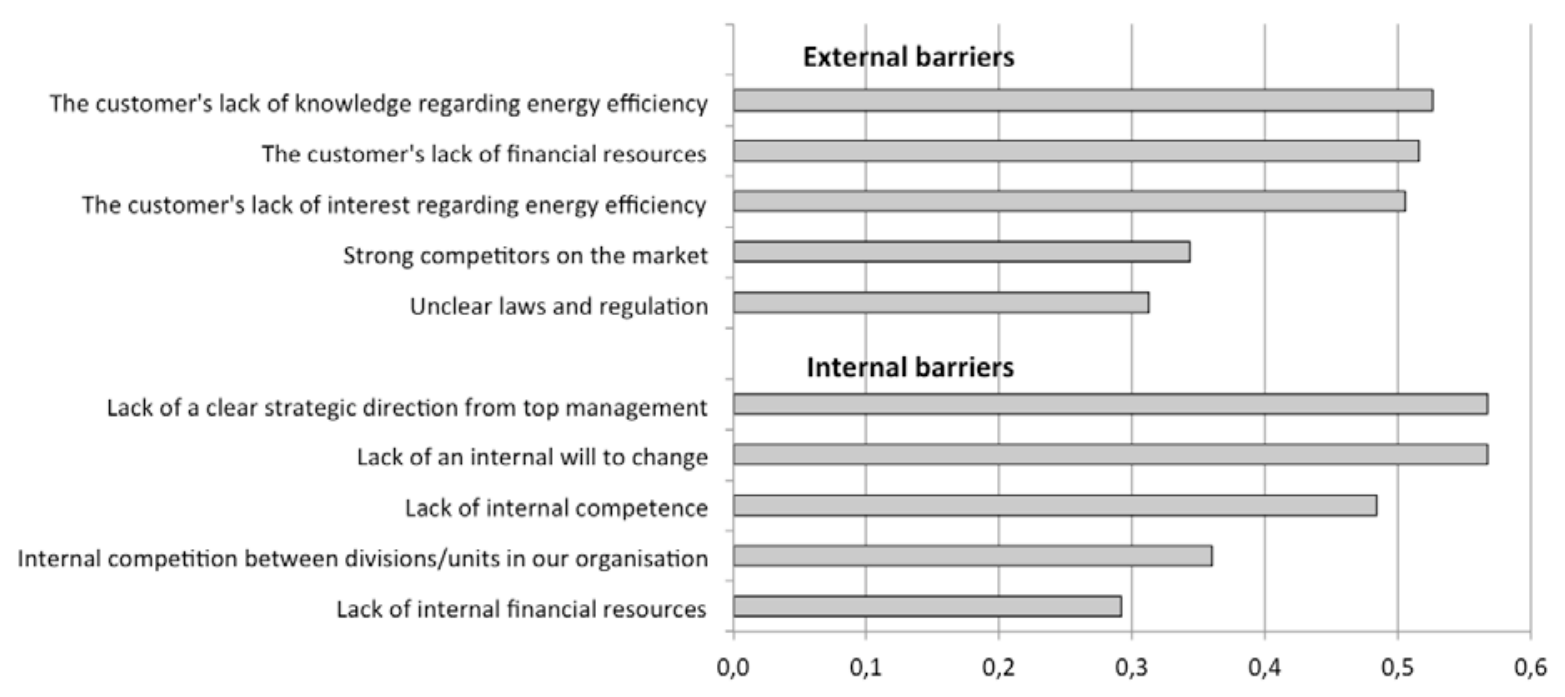

Figure 5. Responses regarding the perceived barriers to energy services. The barriers were ranked according to the respondents' answers (based on the Likert scale 1 to 7 ).

This study finds that a lack of financial resources does not represent a major barrier. This is surprising in relation to previous international findings showing that a lack of financing is indeed a major barrier to service provision among energy companies (Vine, 2005). One possible explanation for this divergence, supported by our interviews, is that the companies examined here are municipally owned and therefore have less strict demands regarding their return on investment, i.e., not as strict demands on profit margins as for private companies. Furthermore, as services generally require less capital investment than do products, and as most studied companies are in the early phases of implementation, which entail relatively low costs, financial considerations are not currently seen as constituting a barrier. However, the cost of sales activities related to energy services may still be problematic, as sales activities tie up valuable resources, often requiring highly qualified energy experts (see Figure 1), and can drastically erode the profit margins of such services.

Regarding the perceived lack of internal competences and top management commitment, these two barriers seem to be moderately important. However, a related barrier, and the most significant one along with lack of strategic direction from top management, is a lack of internal willingness to change. As organizational transitions, particularly cultural transitions from products to services, usually take a long time, for example, due to organizational inertia, this is perhaps unsurprising. Furthermore, in 2008 when Swedenergy initiated the national energy service network for energy supply companies, very few companies had energy services in their portfolios. This is a relatively new phenomenon for most companies, indicating that organizational inertia (Leonard-Barton, 1992) might play a significant 
role and that any cultural transformations are only in their early stages. Moreover, as many of the included energy companies operate on stable markets with little competition, incumbent complacency may be an issue and it might be difficult to find support for more innovation-related activities. If viewing the results in light of previous research, this is in line with Bergmasth and Strid's (2004) finding that there is a lack of strategic direction among energy companies when it comes to energy services. Notably, the larger score of internal barriers indicates clearly that energy service development is mostly an issue to be dealt with, within energy companies. To what extent external pressure such as new governmental legislation can reduce these barriers is an area left for future research.

The present findings indicate that institutional barriers such as unclear laws and regulations, identified as barriers to ESCO development in Europe in previous research by Bertoldi et al. (2006), are not perceived as major barriers in our study. This indicates that the market boundaries are understood and seen as well-defined by the actors. Furthermore, competition from other ESCOs is not perceived as a major barrier by the energy supply companies. This is in line with indications that the energy service market is fairly immature, with only a moderate and increasing number of actors that are not infringing on each other's market space.

One of the most significant barriers identified here is potential customers' inexperience and immaturity regarding energy services as well as their associated unwillingness to commit (e.g., resources) to energy services. Furthermore, customers' lack of financial resources is perceived as a barrier by about half of the respondents. Addressing this barrier may very well be a selling point for more advanced energy services, such as EPCs, as these involve deeper customer commitment, both financially and relationally. Regarding customers' interest, intentions, and knowledge, similar, although somewhat less important, results were found. Finally, it is important to recall that many of the studied energy companies are still relatively immature regarding their activities in energy services, so they might not yet have had the time to fully understand or experience potential barriers. Interestingly, results from over a decade ago reveal similar findings (Bergmasth \& Strid, 2004), once again indicating relatively slow progress (in itself somewhat surprising).

\subsection{Driving forces of energy services in the analyzed companies}

The perceived driving forces of the successful implementation of energy services are divided into external and internal driving forces. External driving forces are primarily related to factors outside the firm, while internal driving forces are primarily related to factors pertaining to the energy company itself. Figure 6 illustrates the respondent's perceived driving forces (weighted) for energy services. 


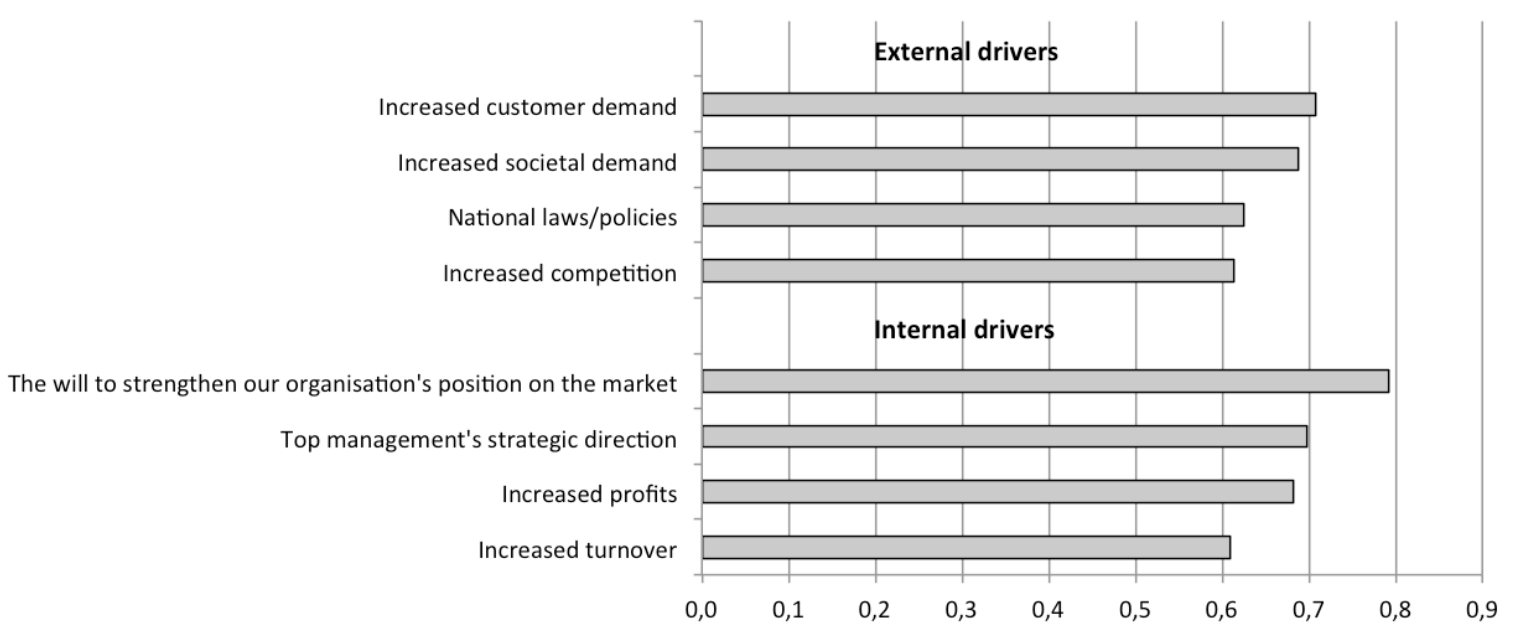

Figure 6. Responses regarding the perceived driving forces of energy services. The driving forces were ranked according to the respondents' answers (based on the Likert scale 1 to 7 ).

Findings of this study regarding driving forces (see Figure 6) indicate that willingness to strengthen the organization's position in the market is the most important internally oriented driving force of energy services. This is interesting, as it indicates an awareness of the company as an actor in a competitive market in a particular social context. This could point to increasing environmental awareness, both internally and in the market as a whole, indicating an increased need to provide products and services that contribute to a more sustainable society. The second most important driver was top management's strategic direction. The issue is further emphasized in the barriers result section, reported in section 4.2, indicating that a lack of strategic direction was a significant barrier. This indicates that establishing a clear strategic direction, with, e.g., measurable goals, is a key issue in implementing energy services. Another conclusion from this, and also pertaining to the existence of organizational inertia discussed above, is that a key actor (and a change agent) in implementing energy services will be found in the top management of an energy company.

Regarding the other internal driving forces, i.e., increased profits (e.g., as services typically have a higher profit margin) and turnover (as in using energy services as a way to increase firm total turnover), these financial driving forces are apparently perceived as somewhat less important and are consistently ranked lower than are the willingness to change and strategic goals. This should likely be interpreted in light of the fact that the participating companies are not privately owned (in the vast majority of cases), meaning that they have not traditionally emphasized profits and turnover to the same extent as more commercial actors. This might in turn also explain why these companies increasingly view environmental considerations as important when promoting energy services. Many municipalities have ambitious sustainability goals that the energy companies must incorporate into their businesses.

The highest ranked external driving force, i.e., increased customer demand, indicates that, unsurprisingly, customers play a crucial role in the successful launch of energy services in the market and that stimulating customer demand and interest are key factors. This is also paralleled in the section on barriers, which indicates that customer-related factors are perceived as major barriers that must be addressed in order to succeed. Research into energy services among industrial companies, however, finds a considerable lack of general trust in ESCOs (Backlund \& Eidenskog, 2013). This suggests that, for the market to develop and for customers to invest in energy services, several actors might need to collaborate. 
The driving force of societal demand (as perceived by the energy companies) was also relatively highly ranked, i.e., it is not solely economic issues that drive the local and regional energy companies. As many of the included energy companies are municipally owned, the societal aspect becomes important. This is also a consequence of a generally increased awareness of these issues in Swedish society (as in many other societies).

\subsection{Results summary}

The results in this study indicate the existence of a supply side interest in providing energy services, where the major challenges seem to concern (a) intra-organizational issues, such a lack of strategic direction and intent, and (b) a perceived view of lack of knowledge, interest, and trust on the part of potential energy service customers. Notably, the studied companies did not rank internal barriers very high. This might be explained by the fact that they have not yet had extensive experience in energy services, potentially leading to the lower ranking of barriers that they have not yet fully experienced or appreciated. Many of the perceived barriers also relate to the companies' lack of a general resource commitment to energy services, a lack manifested throughout their organizations, for example, at both the management and sales levels.

Regarding internal and external driving forces, the most important perceived driving force identified here was the desire to strengthen the organization's position in the market followed by clear strategic goals set by top management. Both the latter driving force and the great relative importance of customer demand as a driving force, together with the corroborating findings on the barrier side, emphasize the importance of these two driving forces for the future successful development of energy services.

\section{Discussion}

\subsection{Managerial implications}

Several managerial implications connected to the discussed barriers and driving forces are of interest and can provide useful insights for managers working with any of the stages of development, sales, and deployment of energy services. Table 4 summarizes the findings of the study and briefly discusses their managerial implications. Although the present results refer to local and regional companies operating in the Swedish energy service market, several of the findings discussed below also apply to similar energy companies operating in other markets. Given that these companies share the main factor of having a local and regional customer base, the managerial implications from this study particularly hold for factors related to strategy, resources, and customers in local and regional energy companies operating in other international markets.

Table 4 Key findings and associated managerial implications.

\begin{tabular}{|l|l|}
\hline \multicolumn{1}{|c|}{ Key findings } & \multicolumn{1}{c|}{ Managerial implications } \\
\hline $\begin{array}{l}\text { Importance of an internal } \\
\text { resource commitment }\end{array}$ & $\begin{array}{l}\text { Ensure the availability of resources throughout the implementation } \\
\text { process }\end{array}$ \\
\hline $\begin{array}{l}\text { Existence of top management } \\
\text { support }\end{array}$ & Find a change champion for energy services among senior managers \\
\hline $\begin{array}{l}\text { Having clear energy service } \\
\text { goals }\end{array}$ & Establish measureable energy service activities \\
\hline $\begin{array}{l}\text { Designing optimal sales } \\
\text { channels }\end{array}$ & $\begin{array}{l}\text { Establish, at least initially, a dedicated sales channel for energy } \\
\text { services }\end{array}$ \\
\hline Establishing clear strategic & Make a clear and committable strategic decision regarding the future \\
\hline
\end{tabular}




\begin{tabular}{|l|l|}
\hline intent and direction & direction and aim of energy services \\
\hline $\begin{array}{l}\text { Lack of customer knowledge, } \\
\text { interest, and trust in energy } \\
\text { services }\end{array}$ & $\begin{array}{l}\text { Invest in relationship building with targeted customers to ensure a } \\
\text { better understanding of customer needs }\end{array}$ \\
\hline $\begin{array}{l}\text { Lack of customer financial } \\
\text { resources }\end{array}$ & $\begin{array}{l}\text { Develop revenue models that emphasize recurring revenues by } \\
\text { minimizing the cost structure for the customer (focus on results } \\
\text { instead of selling “only” heat and electricity) }\end{array}$ \\
\hline
\end{tabular}

While some of the managerial implications are internally focused, others depend on strengthening relationships with customers. One basis for success, however, is the unique direct access to individual customer data that local and regional energy companies often possess. This access could provide a way to get a "foot in the door" regarding energy services and to convince reluctant customers to invest in energy services, consequently opening the market. As an example, Karnouskos et al. (2009) argued that in order to develop holistic energy efficiency strategies, data gathered from all layers of an organization need to be correlated. If an organization is to become more energy-efficient, monitoring and targeting measures are needed (ISO, 2011; BSi, 2009; Kannan \& Boie, 2003). The ability to exploit that "installed base," and existing customer knowledge, has been identified as a potentially important competitive advantage for incumbent firms seeking to expand their business by offering services (Ulaga \& Reinartz, 2011).

As many of the local and regional companies are struggling to make the transition from basic to more advanced services, one key managerial focus is to identify and launch a "threshold service," that is, a service that lets the energy companies move into more advanced services requiring more interaction with their customers' operational and business processes. Such threshold services can also increase customer interest in energy services. The respondents' perception of their potential customer's lack of knowledge, financial resources, and interest regarding energy services can be viewed as problems, but also as business opportunities for the energy companies studied here. Local and regional energy companies can, by being market-building actors, carve out positions and reputations on their specific market that enable future success. Success in this area, however, depends on relationship building with targeted customers to ensure that the energy company fully understands customer needs.

\subsection{Policy implications}

A number of different policy measures exist with the aim to promote adoption of energy services such as standardized contracts, investment subsidies, and tax reductions (Jensen et al., 2013). This study indicates relatively slow progress in the area of energy services as offered by local and regional energy companies, thus corroborating findings in previous studies (Bergmasth \& Strid, 2004; LindgrenSoroye \& Nilsson, 2010). Recent findings also reveal that some energy service markets are in fact shrinking or in stagnation, e.g. the Belgian and Japanese energy service markets (see e.g. Panev et al. 2014), one major reason for this being the existence of barriers for wider market exploration for ESCOs, e.g. high transaction costs in the contractual process (Cornelis et al., 2015). Results from Jensen et al. (2013), however, find, in contrast, a growing market for several EU member states. Indepth analyses regarding international ESCO-markets are also presented in reports from the Joint Research Center (Bertoldi et al., 2014; Panev et al. 2014).

Taking the relatively slow pace of market development of the Swedish energy service market into account, for Swedish policy makers it could be worth considering the adoption of various policy approaches to further accelerate the market development. For example, one such initiative is the Belgian ESCO Association (Belesco), which was founded in 2010. A similar ESCO association in 
Sweden could create networking opportunities and also offer advice to the local and regional energy companies. As these companies often suffer from a lack of resources regarding their energy services, such an initiative could be a valuable resource. Moreover, standardized contracts, as emphasized by Sorrell (2007), can also be a potential policy measure worth considering. However, such an approach has been criticized by Forsberg et al. (2007) stating that "dialogue with stakeholders in Sweden made it clear that there was no real need nor interest for fully standardized RFQ's and contracts in Sweden, neither from the customers nor from the ESCO industry.”.

\section{Conclusions}

This research was an examination of barriers to and driving forces for the successful implementation of energy services from a local and regional energy company perspective. Previous researchers, e.g., Sorrell (2007) and Bergmasth and Strid (2004), have applied a transaction cost economics approach to understanding energy services. Our study's theoretical approach combining resource and service transition with perceived barriers to and driving forces for energy services has, to the authors' awareness, not been used previously. The study thus adds to the growing scientific literature of applied studies on the energy service markets, and available theories and methods on how to further build models enhancing our understanding of this complex matter.

An interesting finding related to policy implications when comparing this study with other international studies was thus that the energy service market development from a policy point of view is rather complex, with various initiatives being present in different countries. Further comparative research initiatives between national markets are suggested in order to further explore the issue of policy measures for improved energy service adoption. Local and regional energy providers can, as suggested in this research, be key actors in the process of developing the energy service market, and thus it is of importance to understand how to simulate the implementation process. It is also important to understand the existing barriers for the adoption of energy services, and how to overcome them, in these companies.

\section{Acknowledgements}

The authors would like to express their sincere gratitude to the anonymous reviewers for valuable comments on earlier versions of the paper. The authors are also indebted to the respondents at the studied companies for giving freely of their time and attention to participate in this study. Finally, the authors are grateful to the Swedish Energy Agency for funding this research.

\section{References}

Backlund, S. \& Thollander, P. (2011). The energy-service gap: What does it mean? In Proceedings of the European Council for an Energy Efficient Economy’s Summer Study, 6-11 June.

Backlund, S., Thollander P., Palm, J. \& Ottosson, M. (2012). Extending the energy efficiency gap. Energy Policy, 51, 392-396.

Backlund, S. \& Eidenskog, M. (2013). Energy service collaborations - it's a question of trust, Energy Efficiency, 6, 511-521

Barney, J. B. (1991). Firm resources and sustained competitive advantage. Journal of Management, 17. 
Barney, J. B. \& Hesterley, W. S. (2005). Strategic Management and Competitive Advantage. New Jersey: Pearson-Prentice Hall.

Bergmasth, M., Lewald, A., Nilsson, L., \& Strid, M. (2000). The role of energy efficiency in the deregulated Swedish electricity market. ACEEE American Council for an Energy-Efficient Economy. Pacific Grove, CA, USA, 2000.

Bergmasth, M. \& Strid, M.(2004). Energitjänster på en avreglerad marknad. För en effektivare energianvändning?. Bokförlaget Bas, Handelshögskolan, Göteborg,

Bertoldi, P., Boza-Kiss, B., Panev, S. \& Labanca, N (2014). The European ESCO Market Report 2013. Report EUR 26691 EN. Joint Research Center, Ispra, Italy. Download at:

http://iet.jrc.ec.europa.eu/energyefficiency/publication/european-esco-market-report-2013 (2016-0212).

Bertoldi, P., Rezessy, S., \& Vine, E. (2006). Energy service companies in European countries: Current status and a strategy to foster their development. Energy Policy, 34, 1818-1832.

Brunke, J. C., Johansson, M., \& Thollander P. (2014). Empirical investigation of barriers and drivers to the adoption of energy conservation measures, energy management practices and energy services in the Swedish iron and steel industry. Journal of Cleaner Production, 84, 509-525.

Chirumalla, K. (2013). Managing knowledge for product-service system innovation: The role of Web 2.0 technologies. Research Technology Management, 56, 45-53.

Cornelis, E., Kimura, O., Karlsson, M., Paramonova, S., Thollander, P., Jiménez Navarro, JP., Morales, I., Weibøl Bertelsen, C., 2015. IEA IETS Annex XVI Energy Efficiency in SMEs Task IV: Energy services and business models for industrial SMEs. International Energy Agency, Paris.

Dangelico, R. M. \& Pontrandolfo, P. (2013). Being 'green and competitive': The impact of environmental actions and collaborations on firm performance. Business Strategy and the Environment, doi:10.1002/bse.1828

DeCanio, S. (1993). Barriers within firms to energy efficient investments. Energy Policy, 9(1), 906914.

Eggert, A., Hogreve, J., Ulaga, W., \& Muenkhoff, E. (2014). Revenue and profit implications of industrial service strategies. Journal of Service Research, 17(1), 23-39.

Eisenhardt, K. M. \& Graebner, M. E. (2007). Theory building from cases: Opportunities and challenges. Academy of Management Journal, 50, 25-32.

Forsberg, A., Lopes, C., \& Öfverholm, E. (2007). How to Kick Start a Market for EPC. Lessons Learned from a Mix of Measures in Sweden. Available online: http://www.eceee.org/conference_proceedings/eceee/2007/Panel_2/2.030/paper 
Gallouj, F. \& Weinstein, O. (1997). Innovation in services. Research Policy, 26(4/5), 537-556.

Gebauer, H., Fleisch, E., \& Friedli, T. (2005). Overcoming the service paradox in manufacturing companies. European Management Journal, 23(1), 14-26.

Hirst, E. \& Brown, M. A. (1990). Closing the efficiency gap: Barriers to the efficient use of energy. Resources, Conservation and Recycling, 3(4), 267-281.

Jaffe, A. \& Stavins, R. (1994). The energy-efficiency gap. What does it mean. Energy Policy, 22(10), 804-810.

Jensen, J. O., Nielsen, S. B., \& Hansen, J.R. (2013). Greening Public Buildings: ESCO-contracting in Danish Municipalities. Energies, 6(5), 2407-2427.

Kindström, D., Kowalkowski, C. \& Brashear, T. (2015). Adding services to product-based portfolios: An exploration of the implications for the sales function, Journal of Service Management, 26(3), 372393.

Kindström, D. \& Kowalkowski, C. (2009). Development of industrial service offerings: A process framework. Journal of Service Management, 20(2), 156-172.

Lindgren Soroye, K. \& Nilsson, L. J. (2010). Building a business to close the efficiency gap: The Swedish ESCO Experience, Energy Efficiency, 3, 237-256.

Leonard-Barton, D. (1992). Core capabilities and core rigidities: A paradox in managing new product development. Strategic Management Journal, 13, 11-125.

Magnusson, D. (2012). Swedish district heating sector - A system in stagnation: Current and future trends in the district heating sector. Energy Policy, 48, 449-459.

Marino, A., Bertoldi, P., Rezessy, S., \& Boza-Kiss, B. (2011). A snapshot of the European energy service market in 2010 and policy recommendations to foster a further market development, Energy Policy, 39(10), 6190-6198.

Matthyssens, P. \& Vandenbempt, K. (2010). Service addition as business market strategy:

Identification of transition trajectories. Journal of Service Management, 21(5), 693-714.

Okay, N. \& Akman, U. (2010). Analysis of ESCO activities using country indicators. Renewable and Sustainable Energy Reviews, 14, 2760-2771.

Okkonen, L. \& Suhonen, N. (2010). Business models of heat entrepreneurship in Finland. Energy Policy, 38, 3443-3452.

Painuly, J. P., Park, H., Lee, M. K., \& Noh, J. (2003). Promoting energy efficiency financing and ESCOs in developing countries: Mechanisms and barriers. Journal of Cleaner Production, 11, 659665.

Panev, S., Labanca, N., Bertoldi, P., Serrenho, T., Cahill, C. \& Boza Kiss, B. (2014). ESCO Market Report for Non-European Countries 2013. Report EUR 26989 EN. Joint Research Center, Ispra, Italy. 
Download at: http://iet.jrc.ec.europa.eu/energyefficiency/publication/esco-market-report-noneuropean-countries-2013 (2016-02-12)

Pätäri, S. \& Sinkkonen, K. (2014). Energy service companies and energy performance contracting: Is there a need to renew the business model? Insights from a Delphi study. Journal of Cleaner Production, 66, 264-271.

Prahalad, C. K. \& Hamel, G. (1989). Strategic intent, Harvard Business Review, Feb.

SEA (2013). Energitjänster i Sverige - Statusrapport för tjänster för energieffektivisering. ER 2013:22.

Sernhed, K. \& Jeppesen, J. (2009). Från bulkleverantör till energipartner - En kartläggning av energitjänster i svenska fjärrvärmeföretag, Svensk Fjärrvärme AB, Fjärrsynrapport (In Swedish).

Sernhed, K. \& Skoglund P. (2012). Energitjänster - Med kunden i centrum intervjuer med fastighetsbolag, bostadsrättsföreningar och villakunder, Svensk Fjärrvärme AB, Fjärrsynrapport (In Swedish)

Soratana, K., \& Marriott J. (2010). Increasing innovation in home energy efficiency: Monte Carlo simulation of potential improvements. Energy and Buildings, 42, 828-833.

Sorrell, S. (2007). The economics of energy service contracts. Energy Policy, 35, 507-521.

Sovacool, B.K. (2013). Expanding renewable energy access with pro-poor public private partnerships in the developing world. Energy Strategy Reviews, 1, 181-192.

Stewart, D. W. \& Shamdasani, P. N. (1990). Focus groups: Theory and Practice. Thousand Oaks, CA: Sage Publications.

Sutherland, R. J. (1996). The economics of energy conservation policy. Energy Policy, 24 (4), 361370.

Thollander, P., Palm, J., \& Sakao, T. (2010). Energy services in industry - an interdisciplinary approach with engineering and social science aspects. In Proceedings of the IPS2 Conference, 51-56.

Thollander, P., \& Ottosson, M. (2008). An energy efficient Swedish pulp and paper industry: exploring barriers to and driving forces for cost effective energy efficiency investments. Energy Efficiency, 1, 21-34.

Tuli, K. R., Kohli, A. K. \& Bharadwaj, S. G. (2007). Rethinking customer solutions from product bundles to relational processes. Journal of Marketing, 71(July), 1-17.

Ulaga, W. \& Loveland, J. M. (2014). Transitioning from product to service-led growth in manufacturing firms: Emergent challenges in selecting and managing the industrial sales force. Industrial Marketing Management, 43(1), 113-125.

Ulaga, W. \& Reinartz, W. (2011). Hybrid offerings: How manufacturing firms combine goods and services successfully. Journal of Marketing, 75(November), 5-23. 
Vine, E. (2005). An international survey of the energy service company ESCO industry. Energy Policy, 33, 691-704.

Weitz, B. A. \& Bradford, K. D. (1999). Personal selling and sales management: A relationship marketing perspective. Journal of the Academy of Marketing Science, 27, 241-254.

Visnic, I. \& Looy, B. V. (2013). Servitization: Disentangling the impact of service business model innovation on manufacturing firm performance. Journal of Operations Management, 31(4), 169-180.

Wood, S. R. \& Rowley, P. N. (2011). A techno-economic analysis of small-scale, biomass-fuelled heat and power for community housing. Biomass Bioenergy, 35, 3849-3858.

Yin, RK. (2003). Case Study Research, Design and Methods. Newbury Park: Sage Publications.

York, C. M., Blumstein, C., Krieg, B., \& Schipper, L. (1978). Bibliography in institutional barriers to energy conservation. Lawrence Berkeley Laboratory and University of California, Berkeley. 


\section{Appendix: Questionnaire}

The questionnaire was sent out in Swedish. In this appendix, only selected parts pertaining to the analyses made in this article have been translated and included.

Question: How many people in your company work with energy services?

0-5 $\square$ 6-10 $\square$ 11-20 $\square$ 21-50 $\square$ More than $50 \square$ Don’t know

Question: What is the turnover for the energy service business area per year in your company?

0-1 MSEK $\square$ 2-5 MSEK $\square$ 6-10 MSEK $\square$ 11-20 MSEK $\square$ 21-50 MSEK $\square$ More than 50 MSEK

Don't know

Question: What is your position in your company? (Free text question)

Question: Which company do you work for? (Free text question)

Question: Based on the collective experience that exists in your company, how would you rate the following driving forces for the implementation of energy services in your Business?

1: Do not agree at all 7: Fully Agree (for all sub- questions below)

- Increased turnover is an important driving force regarding our energy services

- Increased profits is an important driving force regarding our energy services

- The top management's strategic goal is an important driving force regarding our energy services

- The will to strengthen our organization's position on the market is an important driving force regarding our energy services

- Increased customer demand is an important driving force regarding our energy services

- Increased competition is an important driving force regarding our energy services

- Increased societal demand is an important driving force regarding our energy services

- National laws/policies is an important driving force regarding our energy services 
Question: Based on the collective experience that exists in your company, how do you value the following barriers to the implementation of energy services in your company?

1: Do not agree at all

7: Fully Agree (for all sub- questions below)

- Lack of an internal will for change represents a barrier regarding our energy services

- Lack of clear strategic direction from top management is a barrier regarding our energy services

- Lack of internal competence (e.g. energy experts) is a barrier regarding our energy services

- Lack of internal financial resources is a barrier regarding our energy services

- Internal competition between divisions/units in our organization is a barrier regarding our energy services

- The customer's lack of knowledge regarding energy efficiency is a barrier regarding our energy services

- The customer's lack of interest/will regarding energy efficiency is a barrier regarding our energy services

- The customer's lack of financial resources (e.g. regarding investments) is a barrier regarding our energy services

- Strong competitors on the market is a barrier regarding our energy services

- Unclear laws and regulation is a barrier regarding our energy services

Question: Your organization's energy services are sold by: Specify one or more options.

Dedicated energy service salesperson

Salesperson from other units (e.g. district heating)

Energy experts

General sales resources (e.g. central marketing unit)

We don't sell energy services

Other means (including free text answer possibility) 
Question: Your organization's energy services are deployed through: Specify one or more options.

Internal energy experts

Other internal resources

External partners

We don't deliver energy services

Other means (including free text answer possibility)

Question: What types of energy services do you offer for the customer to buy? Enter one or more options

Energy statistics and information

Energy audits

Energy analysis and advice

Direct improvement of energy efficiency at the customer

Financing of investments at the customer

Operations and maintenance

Functional contracts (e.g. contracts agreeing on a set indoor temperature)

Other (including free text answer possibility)

Question: Based on the collective experience available in your company, how do you value the following statements regarding the internal resources in your company?

1: Do not agree at all 7: Fully Agree (for all sub- questions below)

- There are enough resources available to develop energy services in a satisfactory way

- There are enough resources available to sell energy services in a satisfactory way

- There are enough resources available to deploy energy services in a satisfactory way

- It is currently difficult to dedicate personnel to work solely with energy services

- Our organization currently has sufficient competence internally to deliver our energy services

- It is difficult to find the right competence to develop energy services

- It is difficult to find the right competence to sell energy services

- It is difficult to find the right competence to deliver energy services 